\title{
Calendar for Southern Highbush Blueberry Management in Florida ${ }^{1}$
}

\author{
Douglas A. Phillips, Jeffrey G. Williamson, Philip F. Harmon, Oscar E. Liburd, and Peter J. \\ Dittmar $^{2}$
}

Southern highbush blueberries (SHB) are commercially grown throughout Florida in both deciduous and evergreen systems. This calendar addresses general management requirements on a monthly basis for Florida commercial blueberry growers in conventional (nonorganic) systems and should be used in coordination with other UF/IFAS Extension EDIS publications.

\section{December-January}

\section{Disease}

Once bloom occurs, monitor for Botrytis flower blight during cool, wet periods. If present, spray recommended fungicides in rotation. Applications of fungicides prior to a forecasted need for overhead irrigation as freeze protection can help reduce Botrytis severity on plants damaged by low-temperature injury. See EDIS publication PP198, Botrytis Blossom Blight of Southern Highbush Blueberry (https://edis.ifas.ufl.edu/pp119). One tool growers may consider in timing spray applications is the Blueberry Advisory System (BAS) at www.agroclimate.org/BAS, which indicates when weather conditions are favorable for the development of Botrytis and anthracnose fruit rot. January - apply Ridomil to help prevent Phytophthora root rot. See EDIS publication HS1156, 2019 Florida Blueberry Integrated Pest Management Guide (https://edis.ifas.ufl.edu/ hs380).

\section{Insect Pests}

Monitor for blueberry gall midge, and spray recommended insecticides when adults are observed. If traps are not used, spray before floral and vegetative bud break, with a second spray approximately 7-10 days after the first application, following label directions. See EDIS publication ENY-997, Blueberry Gall Midge on Southern Highbush Blueberry in Florida (https://edis.ifas.ufl.edu/in1239). Also scout for scales, southern red mites (Tetranychid) and flat mites or false spider mites (Tenuipalpid), flower thrips, and blueberry bud mites, and if observed use applicable control measures. Nematodes are not known to damage southern highbush blueberries in Florida. See EDIS publication HS1156, 2019 Florida Blueberry Integrated Pest Management Guide (https://edis.ifas.ufl.edu/hs380) for detailed recommendations.

\section{Weeds}

Apply postemergence herbicide if weeds are at densities that hinder bush growth.

1. This document is HS1363, one of a series of the Horticultural Sciences Department, UF/IFAS Extension. Original publication date March 2020. Visit the EDIS website at https://edis.ifas.ufl.edu for the currently supported version of this publication.

2. Douglas A. Phillips, blueberry Extension coordinator; Jeffrey G. Williamson, professor, Horticultural Sciences Department; Philip F. Harmon, professor, Plant Pathology Department; Oscar E. Liburd, professor, Entomology and Nematology Department; and Peter J. Dittmar, associate professor, Horticultural Sciences Department; UF/IFAS Extension, Gainesville, FL 32611.

The use of trade names in this publication is solely for the purpose of providing specific information. UF/IFAS does not guarantee or warranty the products named, and references to them in this publication do not signify our approval to the exclusion of other products of suitable composition. Use pesticides safely. Read and follow directions on the manufacturer's label.

The Institute of Food and Agricultural Sciences (IFAS) is an Equal Opportunity Institution authorized to provide research, educational information and other services

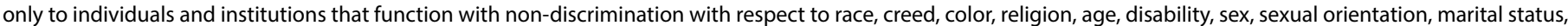

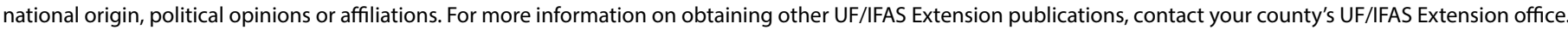
U.S. Department of Agriculture, UF/IFAS Extension Service, University of Florida, IFAS, Florida A \& M University Cooperative Extension Program, and Boards of County Commissioners Cooperating. Nick T. Place, dean for UF/IFAS Extension. 


\section{Hydrogen Cyanamide}

Hydrogen cyanamide can help accelerate vegetative budbreak and concentrate harvests for SHB in deciduous systems. Consider applying hydrogen cyanamide (marketed as Dormex, BudPro, and Krop-Max) in deciduous production systems, in particular those with weak or delayed leaf canopy development and heavy fruit loads. However, at higher concentrations hydrogen cyanamide can cause floral bud injury and reductions in yield, especially in some cultivars that are more sensitive to it, including 'Jewel' and 'Primadonna'. Growers should do test applications by cultivar on small sections to determine safe concentrations. In addition, application should be made before $20 \%$ of the floral buds are at or past stage 3 (separation of bud scales) and after sufficient chilling has occurred to minimize floral bud damage. See further discussion in EDIS publication HS976, Reproductive Growth and Development of Blueberry (https://edis.ifas.ufl.edu/hs220).

\section{Freeze Protection}

Monitor forecasted and actual temperatures and utilize freeze protection strategies as needed. See EDIS publication HS968, Protecting Blueberries from Freezes in Florida (https://edis.ifas.ufl.edu/hs216).

\section{Pruning}

Dormant pruning can be performed to maintain appropriate plant structure and size. Removal of approximately $25 \%$ of old canes should be done annually beginning when a plant is five to six years old to promote the growth of new canes. Low branches, weak growth, and damaged wood can also be removed at this time.

\section{Bees}

Managed honey bees and bumble bees provide essential pollination services in commercial blueberry fields. Have honey bees (and bumble bees if applicable) delivered; ideally they should be placed in the field after $10 \%$ bloom but before $20 \%$ bloom. On large farms, hives should be distributed throughout the farm to the extent it still allows access to bee providers. Confirm health of colonies upon delivery; at least 8 frames per hive should have adults, and at least 6 frames should have brood in the cells, with good activity into and out of the hives and on the bushes. Consider adding additional honey bee or bumble bee hives if there is a heavy, concentrated bloom across the farm, nearby competing crops or wild plants blooming at the same time, or ongoing poor weather conditions (cold, windy, or overcast). See additional details in EDIS publication ENY-172, Pollination Best Practices in Southern
Highbush Blueberry in Florida (https://edis.ifas.ufl.edu/ in1237).

\section{February-March}

\section{Disease}

Monitor for Botrytis and control as needed. Apply recommended fungicides in rotation for control of anthracnose and/or Alternaria fruit rot at petal fall, 10-14 days after petal fall, 20-24 days after petal fall, and prior to harvest.

\section{Insect Pests}

Monitor for gall midge, flower thrips, and blueberry bud mites, and apply recommended controls, if available.

\section{Weeds \\ FEBRUARY}

Apply postemergence herbicide if weeds are at densities that hinder bush growth.

\section{MARCH}

Apply a preemergence herbicide for warm-season weeds (tank-mix with a postemergence herbicide if weeds are at a density that hinders bush growth).

\section{Freeze Protection}

Monitor forecasted and actual temperatures and utilize freeze protection strategies as needed.

\section{Bees}

Monitor health of colonies and watch for appropriate level of bee activity into and out of the hives and on the blueberry bushes. Consider adding additional hives if there is a heavy, concentrated bloom across the farm, competing crops or wild plants nearby blooming at the same time, or ongoing poor weather conditions (cold, windy, or overcast). Bee hives should be kept in the field through the end of bloom for all cultivars.

\section{April \\ Disease}

Apply recommended fungicides in rotation for control of anthracnose and/or Alternaria fruit rot; promptly harvest and cool ripe fruit.

\section{Insect Pests}

Monitor for gall midge and flower thrips and control as needed. Spray recommended insecticides to control spotted wing drosophila (SWD), and promptly harvest ripe 
fruit. If living north of Lake City and there is a history of blueberry maggot, establish yellow sticky traps to monitor for blueberry maggot adults. Also, in infested areas, start scouting for adult Diaprepes (citrus) root weevils (see EDIS publication ENY999, Diaprepes Root Weevil on Southern Highbush Blueberry in Florida [https://edis.ifas.ufl.edu/ in1241]) and adult flatheaded borers on the blueberry foliage. No pesticide is labeled in blueberry for citrus root weevil and flatheaded borer; however, some of the cover sprays for spotted wing drosophila will control these pests.

\section{Weeds}

Apply postemergence herbicide if weeds are at densities that hinder bush growth.

\section{May}

\section{Disease}

Monitor for postharvest leaf diseases (rust, anthracnose, Septoria, target spot, Phyllosticta) and apply recommended control measures. See EDIS publication PP-348, Florida Blueberry Leaf Disease Guide (https://edis.ifas. ufl.edu/pp348). See also Table 1 of this article, "Calendar of blueberry leaf disease activity and potential fungicide management options."

\section{Insect Pests}

Continue with insecticide sprays for spotted wing drosophila for the remaining ripe fruit that is left on the bush. Continue monitoring for blueberry maggot in affected areas. Continue monitoring for adult citrus root weevils and adult flatheaded borers in infested areas. Postharvest, spray to control blueberry bud mite if present or observed in prior season. Scout for chilli thrips (leaf curling and bronzing) and blueberry flea (leaf) beetle (shot holes in the leaf) and apply recommended control measures if present. See EDIS publication EENY463, Chilli thrips Scirtothrips dorsalis Hood (Insecta: Thysanoptera: Thripidae) (https:// edis.ifas.ufl.edu/in833).

\section{Pruning}

After harvest is complete, hedge back bushes to stimulate new vegetative growth, immediately spraying with a recommended fungicide to minimize the risk of fungal pathogens infecting through pruning wounds.

\section{Weeds}

Apply a preemergence herbicide after harvest (tank-mix with a postemergence herbicide if weeds are at densities that hinder bush growth).

\section{June-October}

\section{Disease}

Scout for algal stem blotch. See EDIS publication PP344, Algal Stem Blotch in Southern Highbush Blueberry in Florida (https://edis.ifas.ufl.edu/pp344). Selectively prune out canes infected with algal stem blotch, Botryosphaeria stem blight, and dead canes. Continue to monitor and manage leaf diseases. On farms managing bacterial wilt, begin monthly through-irrigation or banded-bed applications of a phosphorous acid product. See EDIS publication PP332, Bacterial Wilt of Southern Highbush Blueberry Caused by Ralstonia solanacearum (https://edis.ifas.ufl.edu/pp332). June-Apply Ridomil to help prevent Phytophthora root rot.

\section{Insect Pests}

Scout for flea beetles, adult and larval citrus root weevil, adult and larval flatheaded borer, chilli thrips, and southern red and flat mites in affected areas, and apply recommended control measures if present. October-Spray applicable insecticides or miticides to control blueberry bud mite (if present or observed in prior season) and fall webworm.

\section{Weeds}

\section{JUNE, JULY, AUGUST, OCTOBER}

Apply postemergence herbicide if weeds are at densities that hinder bush growth. August-Apply preemergence herbicide if summer rainfall has been heavy.

\section{SEPTEMBER}

Apply a preemergence herbicide for cool-season weeds (tank-mix with a postemergence herbicide if weeds are at a density that hinders bush growth).

\section{Leaf Tissue Sample Collection}

Leaves should be collected for tissue nutrient analysis in late June or early July, depending on how quickly vegetative growth occurs following summer pruning. Select samples from fully expanded leaves in the middle of a recent summer growth flush.

\section{November}

\section{Disease}

Monitor and manage leaf diseases, particularly in evergreen systems. 


\section{Insect Pests}

Begin monitoring for blueberry gall midge and spray recommended insecticides when adults are observed. If traps are not used, spray right before floral budbreak, with a second spray approximately ten days after the first application, following label directions. See EDIS publication ENY-997, Blueberry Gall Midge on Southern Highbush Blueberry in Florida (https://edis.ifas.ufl.edu/in1239). Continue monitoring for southern red mites and flat mites, and spray miticides and insecticides that have miticidal effects.

\section{Weeds}

Apply postemergence herbicide if weeds are at densities that hinder bush growth.

\section{Periodic Management Tasks throughout the Year}

- Monitor substrate pH and maintain between 4.5 and 5.5. A pH above this range can result in poor plant growth and nutritional deficiencies.

- Obtain a lab analysis of foliar tissue at least annually to confirm sufficient nutrient uptake.

- Add pine bark to beds every 2-3 years. Growers should be aware that fresh pine bark can tie up nitrogen for a period of time, so it will be important to monitor plant $\mathrm{N}$ uptake through foliar analysis after applying new pine bark.

- Scout for Botryosphaeria stem blight, and remove infected canes and stems.

- Scout for bacterial scorch (Xylella fastidiosa) and bacterial wilt (Ralstonia solanacearum). Remove and destroy infected plants, apply soil drench with phosphorous acid to help protect surrounding plants, and also apply before replanting in the same spaces. 'Meadowlark' is known to be susceptible to Xylella, and 'Arcadia' is known to be susceptible to Ralstonia, although other cultivars have also become infected. Suspected infection can be confirmed by submitting plants to the UF/IFAS Plant Diagnostic Center (https://plantpath.ifas.ufl.edu/ extension/plant-diagnostic-center/). 


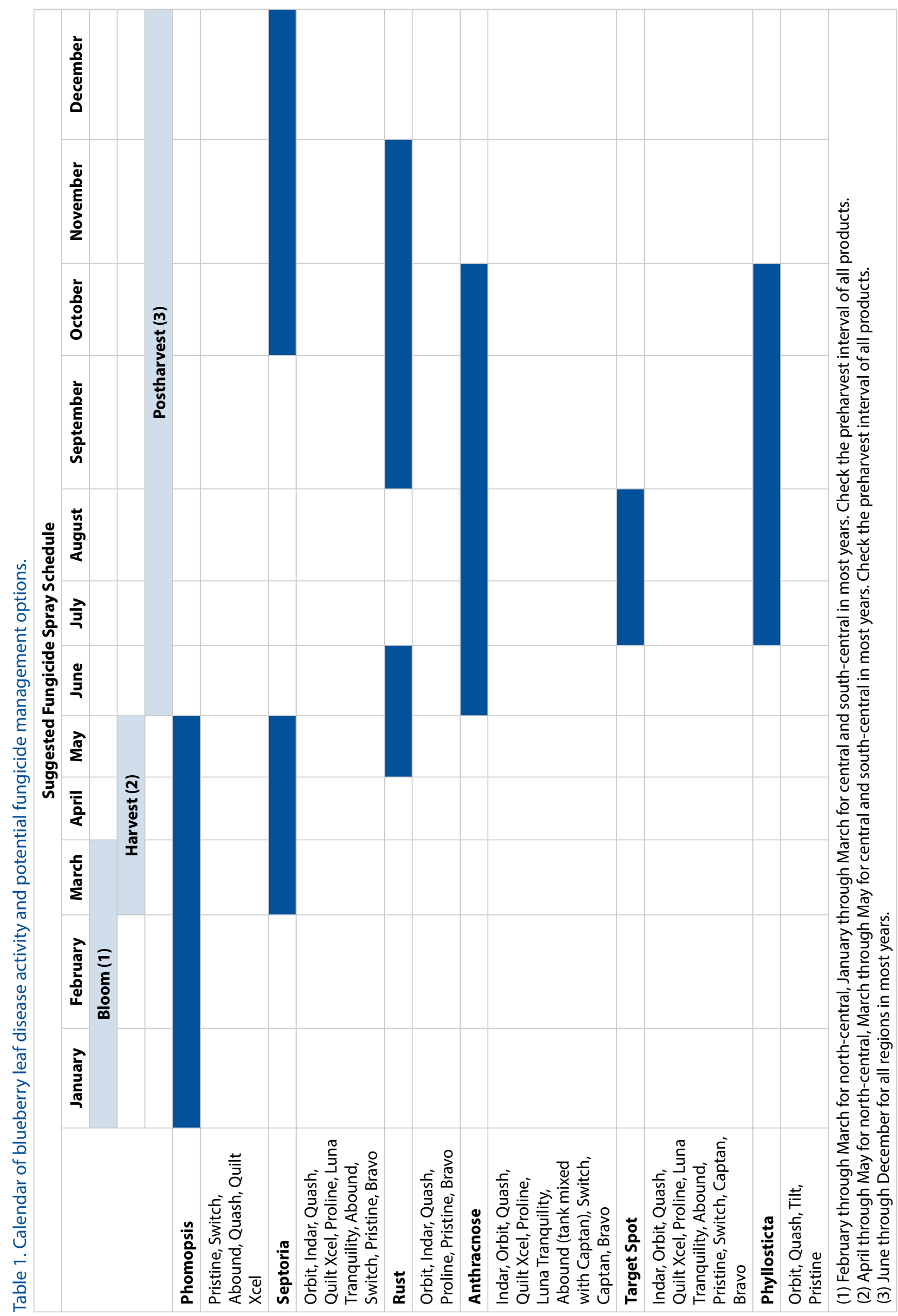




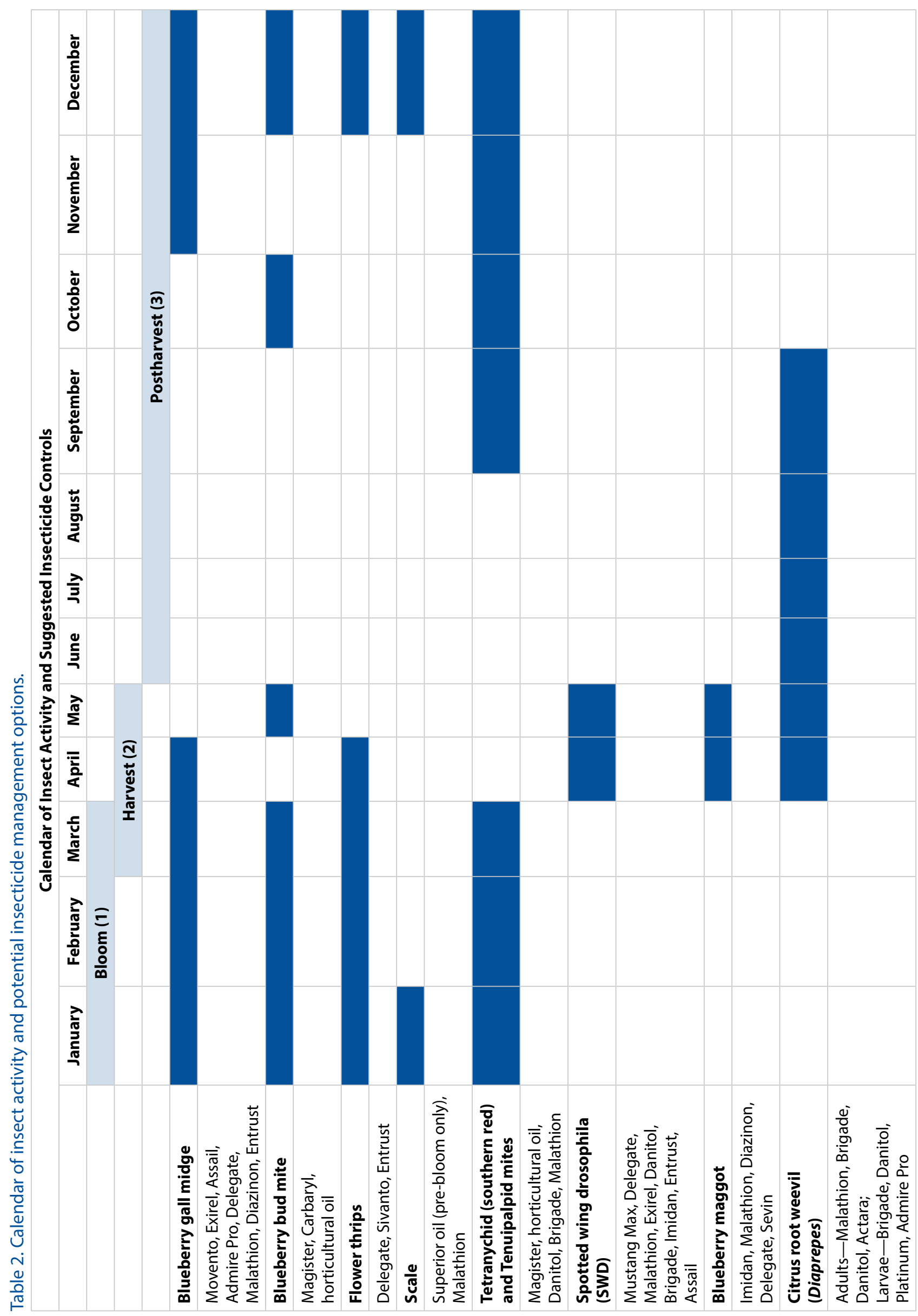




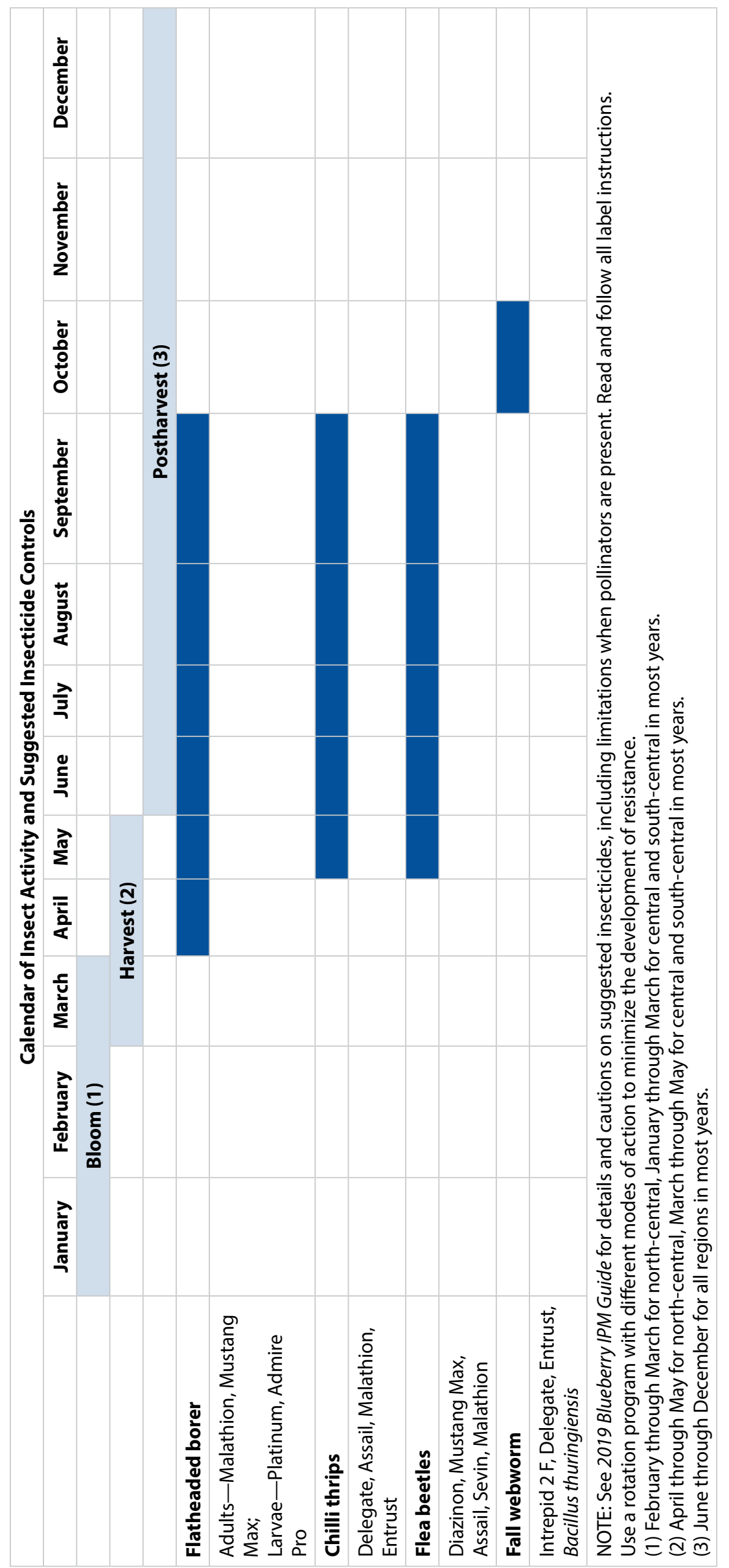

